\title{
Aplikasi Jual Beli dan Info Lomba Burung Surakarta
}

\author{
Kristono*1, Hartati Dyah Wahyuningsih ${ }^{2}$, Ronny Chandra ${ }^{3}$ \\ ${ }_{1,2,3}$ Program Studi Sistem Informasi; STMIK AUB Surakarta, Indonesia \\ e-mail: *1kristono@stmik-aub.ac.id, ${ }^{2}$ hartati.dyah@stmik-aub.ac.id, ${ }^{3}$ ronny.cdr@gmail.com
}

\begin{abstract}
Abstrak
Smartphone merupakan salah satu wujud dari perkembangan teknologi yang dapat mempersempit ruang maupun waktu. Fungsi smartphone sekarang tidak hanya menjadi alat komunikasi saja akan tetapi sudah menjadi sarana hiburan dan juga gaya hidup. Transaksi jual beli burung merupakan salah satu kegiatan yang menjanjikan, setiap tahunnya semakin meningkat dan diminati oleh masyarakat namun terjadi masalah yaitu banyaknya kesibukan yang dimiliki oleh setiap masyarakat. Membuat transaksi jual beli burung dan info lomba burung jadi terhambat. Agar dapat mempermudah masyarakat dalam berbisnis jual beli burung maka dibuat sebuah aplikasi jual beli burung surakarta. Aplikasi jual beli dan info lomba burung surakarta ini bisa menjadi suatu sistem atau aplikasi yang sangat membantu para pecinta burung untuk mencari info jual beli dan lomba burung di wilayah Surakarta. Aplikasi jual beli dan info lomba burung surakarta dibangun menggunakan metode deskriptif dengan jenis penelitian studi kasus di Kota Surakarta. Teknik analisa kelemahan sistem menggunakan analisa PIECES (Perfomance, Information, Economy, Cotrol, Efficiency, dan Service). Untuk teknik pengembangan sistem menggunakan metode waterfall, sedangkan untuk menggambarkan alur data menggunakan UML (Unified Modeling Language) yang terdiri dari use case diagram, Activity diagram, Sequence diagram, Class diagram. Software yang digunakan untuk membangun sistem ini adalah Android Studio dan XAMPP sebagai koneksi database MySQL. Berdasarkan pengujian yang telah dilakukan menggunakan blackbox testing, sistem yang dibangun dapat membantu para pecinta burung dalam mencari info jual beli dan lomba burung.
\end{abstract}

Kata kunci: Jual Beli, Lomba, Aplikasi jual beli dan info lomba burung surakarta, Android Studio, XAMPP

\section{PENDAHULUAN}

Pada dasarnya banyak orang suka memelihara hewan seperti kucing, anjing, ikan, kelinci bahkan mereka juga ada yang memelihara buaya dan ular. Ketertarikan pada hewan bukan hanya untuk dipelihara saja, tetapi juga untuk dibudidayakan. Karena hewan peliharaan dapat sebagai teman, penghibur, atau sebagai penghasil uang.

Tetapi belakangan ini banyak orang minat terhadap hewan yang bersuara merdu, indah, lucu bahkan bisa menjadi penghilang stress sebagai hewan peliharaan, sebagai contoh anjing, namun tidak semua kalangan akan memilih hewan jenis ini dikarenakan oleh berbagai hal. Akan tetapi kali ini banyak orang yang tertarik kepada hewan berparuh bengkok untuk di jadikan hewan peliharaannya, disamping memiliki warna warni, juga memiliki suara yang khas. Di jaman sekarang ini banyak perlombaan burung dan penjualan burung paruh bengkok seperti burung lovebird. Burung ini sangat mudah dipelihara dan tidak terlalu mahal harganya, sehingga banyak masyarakat yang menyukainya. Sudah banyak yang memperkembangbiakkan burung lovebird, dikarenakan semakin meningkatnya peminat.

Transaksi jual beli burung adalah salah satu kegiatan bisnis yang menjanjikan. Kegiatan jual

Received May 3, 2018; Revised May 25, 2018; Accepted June 10, 2018 
beli burung sekarang semakin meningkat dan semakin banyak diminati oleh masyarakat. Jual beli burung yang terus meningkat dari tahun ketahun, seperti penjualan burung lovebird maka diperlukan wadah untuk memudahkan penjual dalam mengenalkan dan mempromosikan dagangannya kepada pembeli, sehingga transaksi penjual dan pembeli dapat berjalan dengan lancar. Tidak hanya aktivitas jual beli burung saja yang diminati oleh masyarakat, tetapi masyarakat juga mengikuti aktivitas perlombaan burung. Perlombaan yang semakin banyak diikuti, tidak hanya usia tua saja yang tertarik untuk mengikuti tetapi usia muda juga banyak yang berminat dalam perlombaan tersebut.

Walaupun semakin banyak website yang menyediakan sarana transaksi jual beli dan informasi lomba burung, namun masyarakat memiliki kesibukan yang berbeda-beda, yang menimbulkan kesulitan dalam melakukan transaksi penjualan atau memantau informasi lomba. Sehingga transaksi penjualan dan informasi lomba burung jadi terhambat. Sedangkan dengan tingginya aktivitas masyarakat membutuhkan sarana yang lebih mudah, praktis dan efisien. Supaya masyarakat dapat melakukan transaksi dimanapun dan kapanpun.

Melihat permasalahan tersebut, maka penulis akan membuat sebuah layanan aplikasi jual beli dan informasi lomba burung yang mencakup daerah menggunakan sistem operasi Android yang diharapkan dapat membantu dan mempermudah para pelaku ekonomi yang tidak lain adalah penjual dan pembeli untuk menemukan sarana yang peraktis, cepat dan efisien. Juga memudahkan para pemberi informasi lomba kepada para pemain atau masyarakat yang mengikuti lomba burung. Aplikasi yang penulis kembangkan ini memiliki fitur berbasis lokasi, dimana user dapat mengetahui posisi penjual barang dan informasi lomba terdekat. Dengan fitur ini, diharapkan akan timbul kepercayan pembeli kepada penjual, dikarenakan pembeli dapat mengetahui lokasi penjual dan mempersingkat waktu pembeli dalam mencari lokasi penjual. Sedangkan keuntungan bagi penjual, fitur berbasis lokasi memudahkan pembeli mengetahui posisinya Fitur lokasi ini, juga menguntungkan bagi para pemain atau peserta lomba untuk mengetahui lokasi-lokasi lomba terdekat dari peserta lomba. Fitur ini sangat menguntungkan para peserta lomba bisa lebih menyingkat waktu dalam mencari lokasi terdekat dari posisi mereka. Salain itu juga diharapkan dengan adanya aplikasi ini, user dapat saling merekomendasikan burung yang mereka jual.

\section{METODE PENELITIAN}

\subsection{Metode Pengembangan Sistem}

Pengembangan aplikasi ini menggunakan metode sekuensial linier (waterfall). Model ini melakukan pendekatan secara sistematis dan berurutan. Disebut waterfall karena tahap demi tahap yang dilalui harus menunggu selesainya tahap sebelumnya dan berjalan berurutan (Pressman, 2010). Penjelasan dari tahap-tahap waterfall model adalah sebagai berikut :

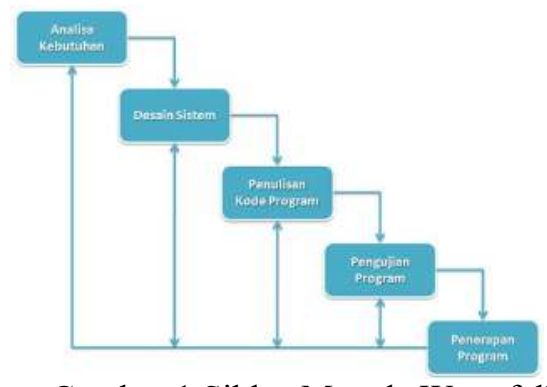

Gambar 1 Siklus Metode Waterfall

Gambar 1 diatas adalah tahapan-tahapan yang dilakukan dalam metode Waterfall, yaitu: 1) Analisis Kebutuhan 
Langkah ini merupakan analisis terhadap kebutuhan sistem. Pengumpulan data dalam tahap ini bisa dilakukan melalui penelitian, wawancara atau study literature. Seorang sistem analisis akan menggali informasi sebanyak-banyaknya dari user sehingga akan tercipta sebuah sistem komputer yang bisa melakukan tugas-tugas yang diinginkan oleh user tersebut. Tahapan ini akan menghasilkan data yang berhubungan dengan keinginan user dalam pembuatan sistem. Data inilah yang akan menjadi acuan sistem analisis untuk menterjemahkan ke dalam bahasa pemrograman.

2) Desain sistem

Tahapan ini dilakukan sebelum melakukan coding. Bertujuan untuk memberikan gambaran apa yang seharusnya dikerjakan dan bagaimana tampilannya. Tahap ini membantu dalam menspesifikasikan kebutuhan hardware dan sistem serta mendefinisikan arsitektur sistem secara keseluruhan. Tahapan ini, Peneliti melakukan beberapa hal perancangan yang akan digunakan dalam pembuatan aplikasi ini, meliputi desain sistem user interface secara rinci, identifikasi dan memilih perangkat keras (hardware) dan perangkat lunak (software) sistem.

3) Penelitian kode program

Coding merupakan penerjemahan desain dalam bahasa yang dikenali oleh komputer. Dilakukan oleh programmer yang akan menerjemahkan transaksi yang diminta oleh user. Tahapan inilah yang merupakan tahapan secara nyata dalam mengerjakan suatu sistem. Dalam artian penggunaan komputer akan dimaksimalkan dalam tahapan ini. Tahapan ini, Peneliti menentukan bahasa pemrograman apa yang akan digunakan, selanjutnya menyiapkan database dan pengkodean program.

4) Pengujian program

Setelah pengkodean selesai maka akan dilakukan pengujian terhadap sistem yang telah dibuat. Tujuan testing adalah menemukan kesalahan-kesalahan terhadap sistem yang telah dibuat dan perbaikan. Tahapan ini, Peneliti menguji sistem yang telah dibuat untuk memastikan bahwa tidak ada kesalahan-kesalahan pada sistem. Jika ada kesalahan maka Peneliti akan melakukan perbaikan terhadap sistem.

5) Penerapan program

Tahapan ini bisa dikatakan final dalam pembuatan sebuah sistem. Setelah melakukan analisis, desain, pengkodean dan pengujian program maka sistem yang sudah jadi akan digunakan oleh user.

\section{HASIL DAN PEMBAHASAN}

\subsection{Pengujian Sistem}

Pada bagian ini menguraikan tentang tahapan-tahapan dalam melakukan pengujian terhadap sistem dan program yang sudah dibuat, sehingga sistem tersebut bebas dari kesalahan agar dapat dilanjutkan pada proses selanjutnya yaitu implementasi sistem dengan menggunakan blackbox testing sebagai metode pengujian sistem.

a. Pengujian blackbox pada validasi halaman admin

Tabel 1 Pengujian form validasi halaman admin

\begin{tabular}{|l|l|l|c|c|}
\hline No & Skenario Pengujian & \multicolumn{1}{|c|}{ Hasil yang diharapkan } & $\begin{array}{c}\text { Hasil } \\
\text { pengujian }\end{array}$ & Kesimpulan \\
\hline 1 & $\begin{array}{l}\text { Admin membuka } \\
\text { aplikasi admin }\end{array}$ & $\begin{array}{l}\text { Sistem menampilkan menu } \\
\text { burung, lomba dan user. }\end{array}$ & $\begin{array}{c}\text { Sesuai } \\
\text { harapan }\end{array}$ & Valid \\
\hline 2 & $\begin{array}{l}\text { Admin memilih menu } \\
\text { burung }\end{array}$ & $\begin{array}{l}\text { Sistem menampilkan informasi } \\
\text { data jual beli burung yang } \\
\text { telah diposting oleh user. } \\
\text { Admin bisa menghapus }\end{array}$ & $\begin{array}{c}\text { Sesuai } \\
\text { harapan }\end{array}$ & Valid \\
\hline
\end{tabular}

GO INFOTECH: JURNAL ILMIAH STMIK AUB Vol. 24, No. 1, Juni $2018: 28-40$ 


\begin{tabular}{|l|l|l|l|}
\hline & $\begin{array}{l}\text { postingan user jika tidak sesuai } \\
\text { dengan ketentuan. }\end{array}$ & \\
\hline
\end{tabular}

Lanjutan Tabel 2 Pengujian form validasi halaman admin

\begin{tabular}{|l|l|l|c|c|}
\hline 3 & $\begin{array}{l}\text { Admin memilih menu } \\
\text { lomba }\end{array}$ & $\begin{array}{l}\text { Sistem menampilkan informasi } \\
\text { data lomba burung. Admin } \\
\text { bisa menambah informasi data } \\
\text { lomba burung. }\end{array}$ & $\begin{array}{r}\text { Sesuai } \\
\text { harapan }\end{array}$ & Valid \\
\hline 4 & $\begin{array}{l}\text { Admin memilih menu } \\
\text { data user }\end{array}$ & $\begin{array}{l}\text { Sistem menampilkan informasi } \\
\text { data user. Admin bisa } \\
\text { menghapus data } \text { user. }\end{array}$ & $\begin{array}{c}\text { Sesuai } \\
\text { harapan }\end{array}$ & Valid \\
\hline
\end{tabular}

b. Pengujian blackbox pada validasi halaman admin

Tabel 3 Pengujian form validasi halaman user

\begin{tabular}{|c|c|c|c|c|}
\hline No & Skenario Pengujian & Hasil yang diharapkan & $\begin{array}{c}\text { Hasil } \\
\text { penguiian }\end{array}$ & Kesimpulan \\
\hline 1 & $\begin{array}{l}\text { User membuka } \\
\text { aplikasi untuk user }\end{array}$ & $\begin{array}{l}\text { Sistem menampilkan menu } \\
\text { beranda, lomba, profil, dan } \\
\text { tentang. }\end{array}$ & $\begin{array}{l}\text { Sesuai } \\
\text { harapan }\end{array}$ & Valid \\
\hline 2 & $\begin{array}{l}\text { User melakukan login } \\
\text { atau mendaftar }\end{array}$ & $\begin{array}{l}\text { Sistem menampilkan form } \\
\text { login untuk login dan form } \\
\text { daftar untuk user yang belum } \\
\text { memiliki akun. }\end{array}$ & $\begin{array}{l}\text { Sesuai } \\
\text { harapan }\end{array}$ & Valid \\
\hline 3 & $\begin{array}{l}\text { User melihat daftar } \\
\text { postingan jual beli di } \\
\text { beranda jual beli }\end{array}$ & $\begin{array}{l}\text { Sistem menampilkan form jual } \\
\text { beli setelah login }\end{array}$ & $\begin{array}{l}\text { Sesuai } \\
\text { harapan }\end{array}$ & Valid \\
\hline 4 & $\begin{array}{l}\text { User meliat detail } \\
\text { postingan }\end{array}$ & $\begin{array}{l}\text { Sistem menampilkan form } \\
\text { detail jual beli }\end{array}$ & $\begin{array}{l}\text { Sesuai } \\
\text { harapan }\end{array}$ & Valid \\
\hline 5 & $\begin{array}{l}\text { User melihat daftar } \\
\text { lomba burung }\end{array}$ & $\begin{array}{l}\text { Sistem menampilkan form } \\
\text { lomba burung }\end{array}$ & $\begin{array}{l}\text { Sesuai } \\
\text { harapan }\end{array}$ & Valid \\
\hline 6 & $\begin{array}{l}\text { User melihat detail } \\
\text { dari lomba burung }\end{array}$ & $\begin{array}{l}\text { Sistem menampilkan form } \\
\text { detail dari daftar lomba burung }\end{array}$ & $\begin{array}{l}\text { Sesuai } \\
\text { harapan }\end{array}$ & Valid \\
\hline 7 & $\begin{array}{l}\text { User melihat profil, } \\
\text { melakukan post jual } \\
\text { burung, melihat } \\
\text { posting jualannya }\end{array}$ & $\begin{array}{l}\text { Sistem menampilkan form } \\
\text { profil pengguna, form jual } \\
\text { burung, dan form posting julan } \\
\text { pengguna }\end{array}$ & $\begin{array}{c}\text { Sesui } \\
\text { harapan }\end{array}$ & Valid \\
\hline 8 & $\begin{array}{l}\text { User melihat tentang } \\
\text { aplikasi }\end{array}$ & $\begin{array}{l}\text { sistem menampilkan fom } \\
\text { tentang aplikasi }\end{array}$ & $\begin{array}{l}\text { Sesuai } \\
\text { harapan }\end{array}$ & Valid \\
\hline
\end{tabular}

\subsection{Pembahasan}

Dalam pembuatan aplikasi ini dibutuhkan suatu implementasi untuk menguraikan program dan analisis dari hasil program yang telah dibuat. Tujuan pembahasan ini adalah untuk mengetahui apakah program yang dibuat sudah bekerja seperti yang diharapkan atau belum. Berikut adalah proses pembahasan interface atau antarmuka program:

a. Halaman form aplikasi Admin burung 


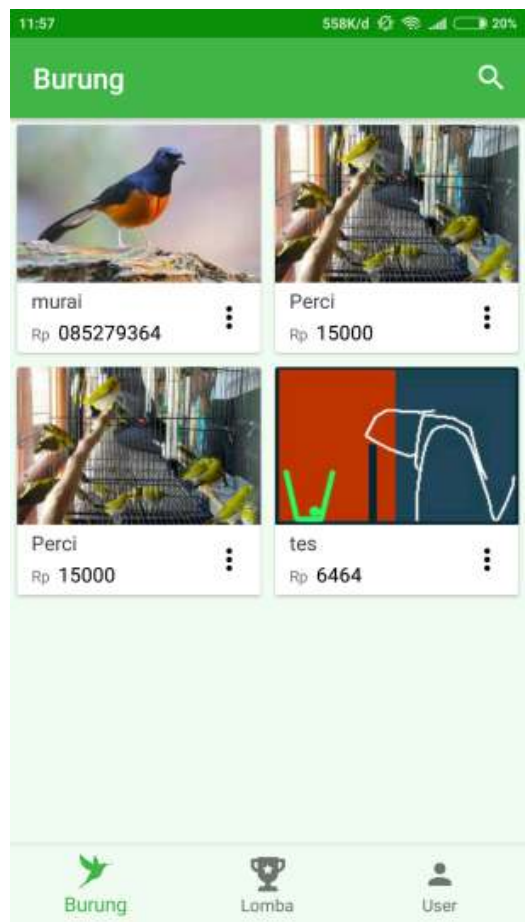

Gambar 2 Halaman form Aplikasi Admin burung

Keterangan gambar 2 Halaman form menu utama aplikasi Admin burung, merupakan halaman awal ketika membuka aplikasi burung, yaitu berisi semua data burung yang sudah diposting oleh user. Bila admin menekan titik 3(tiga) akan muncul keterangan Hapus bila tekan YA maka menghapus Bila menekan TIDAK akan kembli kehalaman sebelumnya.

b. Halaman form lomba

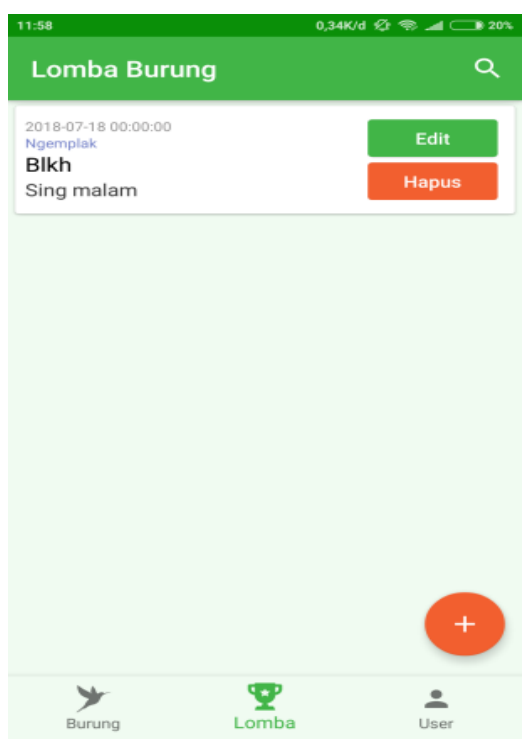

Gambar 3 Halaman form lomba

Keterangan gambar 3 Halaman form lomba, merupakan halaman yang berisi data lomba, yang sudah di input oleh admin. Yang berisiskan tanggal, alamat, dan jam pelaksanaan lomba burung. Admin melakukan perubahan data dengan menekan tombol Edit untuk mengedit data lomba burung yang diposting apabilaada kesalahan. Dan admin menghapus data perlombaan menekan tombol Hapus. Menekan tombol + untuk menambah data lomba burung.

c. Halaman form tambah lomba 


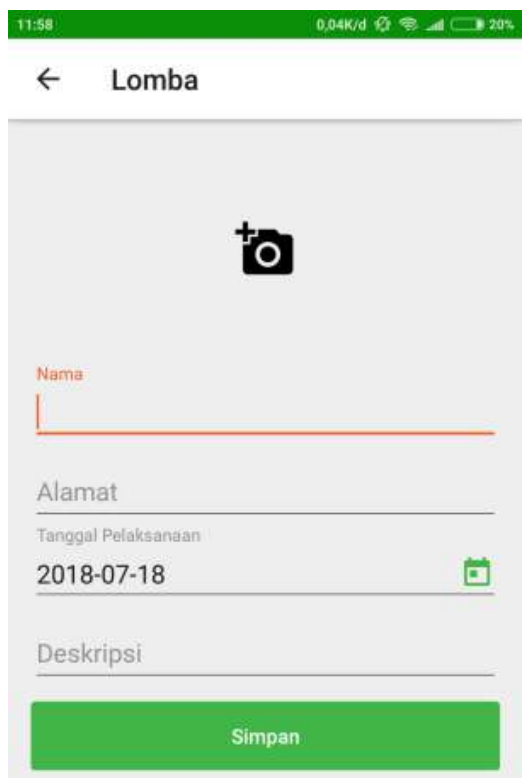

Gambar 4 Halaman form tambah lomba

Keterangan gambar 4 Halaman form tambah lomba, merupakan halaman form untuk menambah data lomba. Berisi nama tempat lomba, alamat, tanggal pelaksanaan, dan mendiskirpsikan lokasi dan waktu lomba. Setelah menekan tombol + untuk menambah data lomba burung asuk kehalaman lomba dengan mengisi nama penyelengara lomba burung, alamat diadakannya lomba burung, tanggal pelaksanaan dan mendeskripsiskan waktu lomba burung. Setelah mengisi data semua tekan tombol Simpan.

d. Halaman form data user

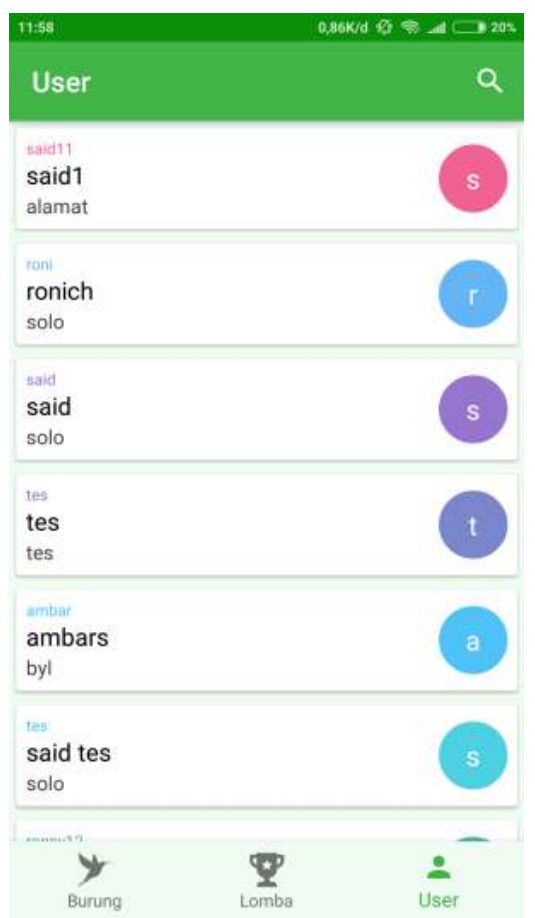

Gambar 5 Halaman form user

Keterangan Gambar 5 Halaman form user, merupakan halaman yang berisi data pengguna. Admin disini hanya dapat menghapus data user tampa meberitahukan kepada 
pengguna. Menekan data pengguna akan muncul Block pengguna tekan Ya untuk mengeblock tekan Tidak bila tidak jadi mengeblock.

e. Halaman form hapus user

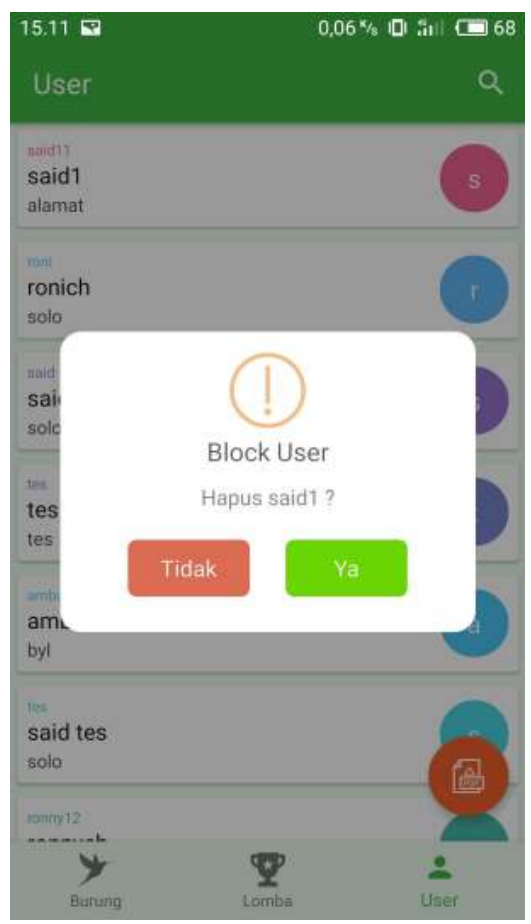

Gambar 6 Halaman form hapus user

Keterangan gambar 6 Halaman form hapus pengguna, berfungsi untuk menghapus data pengguna. Admin menekan tombol Ya untuk menghapus data dan menekan tombol Tidak apabila tidak jadi menghapus data pengguna.

f. Halaman form aplikasi jual beli burung

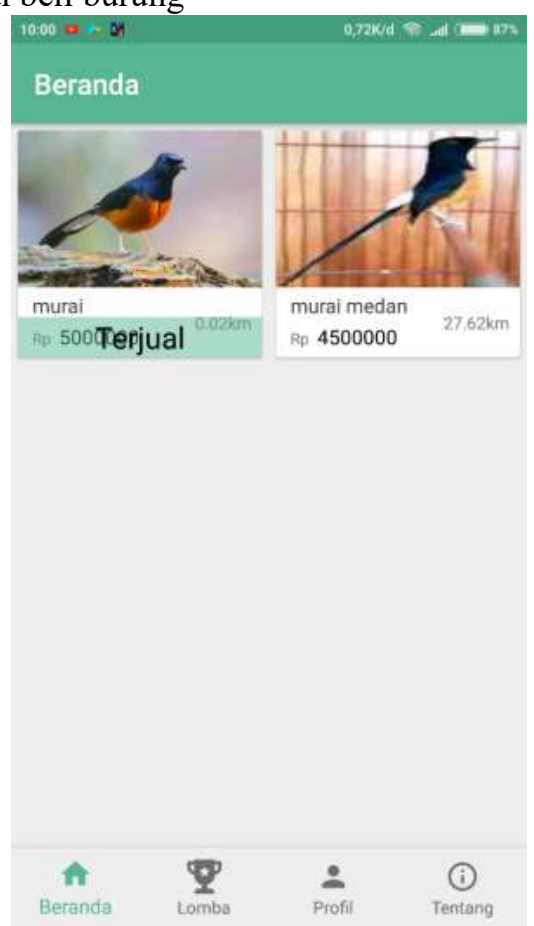

Gambar 7 halaman form aplikasi jual beli 
Keterangan gambar 7 halaman form jual beli , ini merupakan halaman postingan oleh user. Dan user bisa mengetahui jarak terdekat penjual dari user. Disini user bisa burung yang diinginkannya.

g. Halaman form detail burung

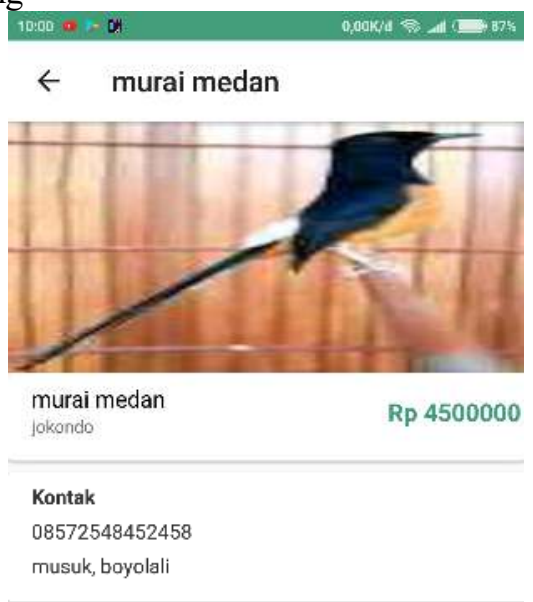

Deskripsi

jos gandos

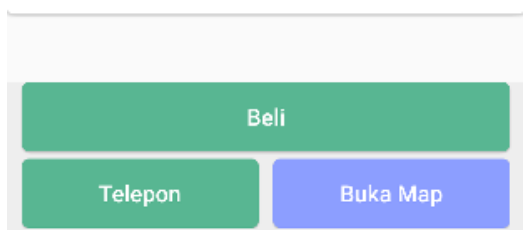

Gambar 8 halaman form detail burung

Keterangan gambar 8 halaman form detail burung ini merupakan halaman yang berisi detail dari yang dipost oleh user, yang berisi harga, nama burung, kontak yang bisa dihubungi dan diskripsi singkat tentang burung yang dijualnya, pembeli bisa langung membeli burung dan menghubungi kontak penjual. Tekan tombol Beli bila pengguna sudah mengkontak penjual dan sesuai dengan harganya, tekan tombol telepon untuk mengetahui kontak penjual tanpa harus menghapalkan yang tertera dan pengguna mengetahui lokasi penjual dengan menekan tombol Buka Map.

h. Halaman form login

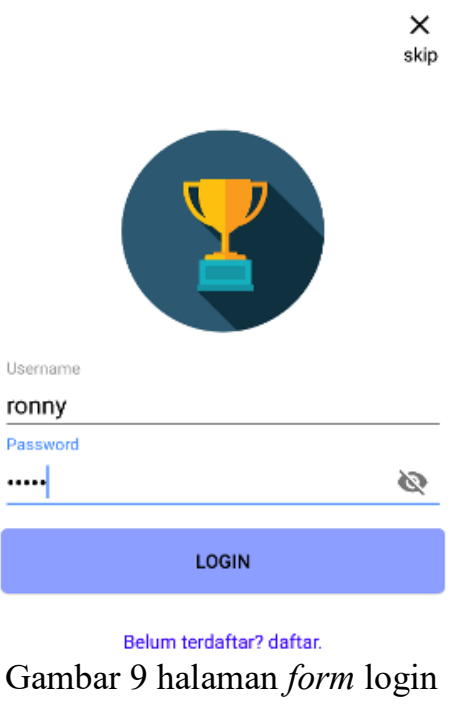


Keterangan gambar 9 halaman form login merupakan halaman sebelum masuk ke halaman utama. User memasukkan username dan password apabila sudah memasukkan klik "LOGIN" akan masuk kehalaman utama.

i. Halaman form daftar

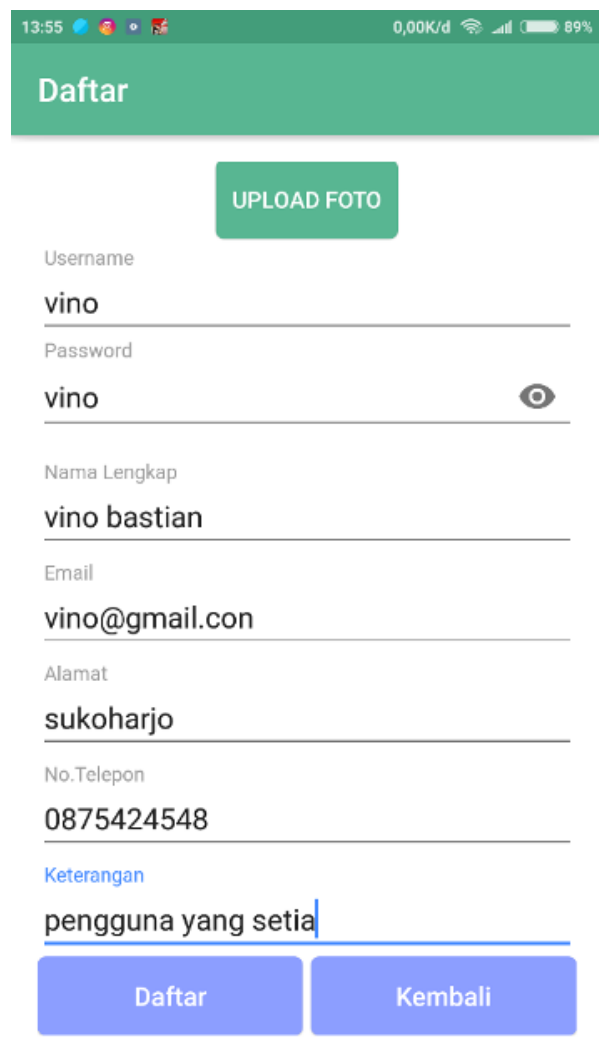

Gambar 10 halaman form daftar

Keterangan gambar 10 halaman form daftar, merupakan halaman untuk mendaftar sebagai user. Yang berisi username, password, nama lengkap, email, alamat, no telepon, keterangan. Bila sudah memasukkan data Dan klik "DAFTAR" untuk mendaftar keAplikasi. Bila tidak jadi mendaftar tekan tombol Kembali.

j. Halaman form profil 

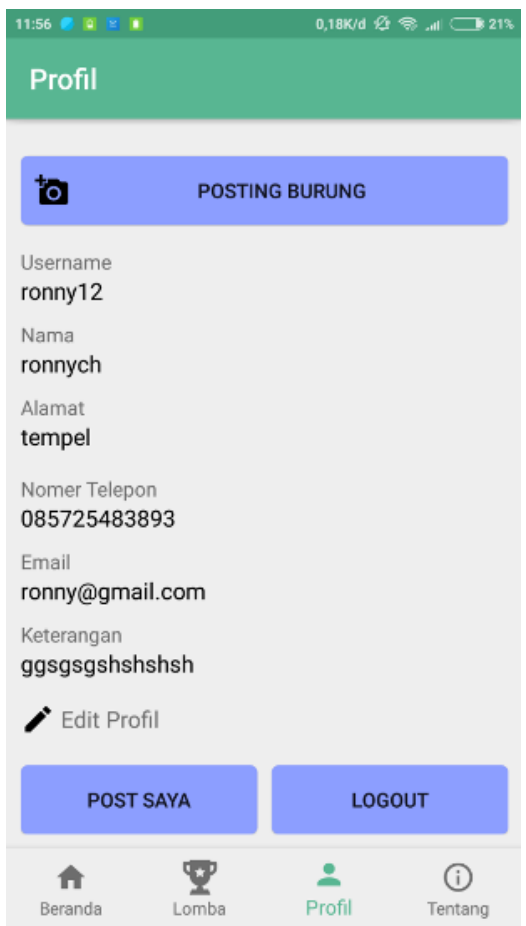

Gambar 11 halaman form profil

Keterangan gambar 11 halaman form profil, merupakan halaman data user atau pengguna saat daftar. Melakukan posting burung dan melihat postingan jualan burung pengguna. Dihalaman ini pengguna bisa mengedit data pengguna dan logout dari aplikasi. Tekan tombol Posting BURUNG untuk memposting jualan burung. Untuk melihat postingan penggukan tekan tombol POST SAYA dan tekan tombol LOGOUT untuk keluar dari halaman aplikasi.

k. Halaman form posting burung

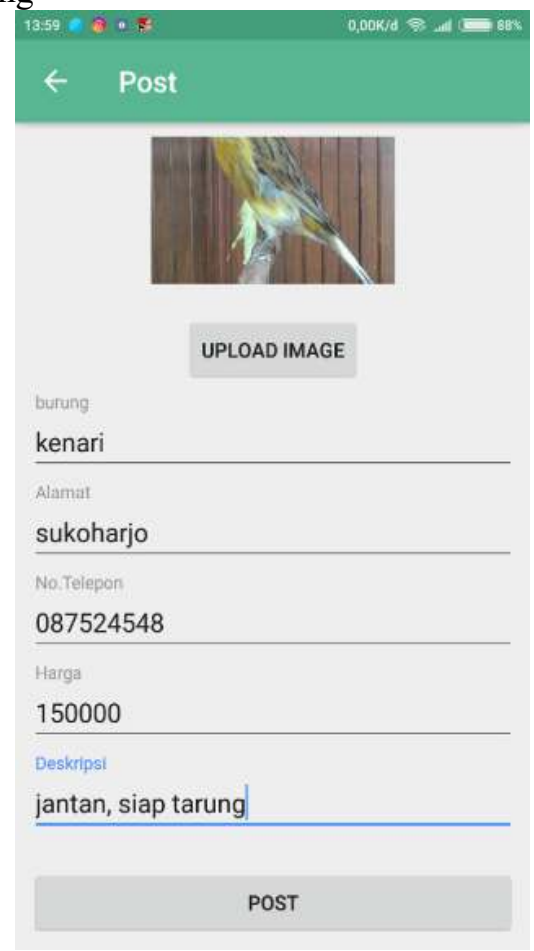


Gambar 12 halaman form posting burung

Keterangan Gambar 12 halaman form posting burung, merupakan halaman untuk memposting jual burung. berisi upload gambar,burung, alamat, no. Telepon, harga, deskripsi. Setalah mengisi data diaplikasi langsung klik POST akan keposting ke halamn beranda jual.

1. Halaman form lomba burung
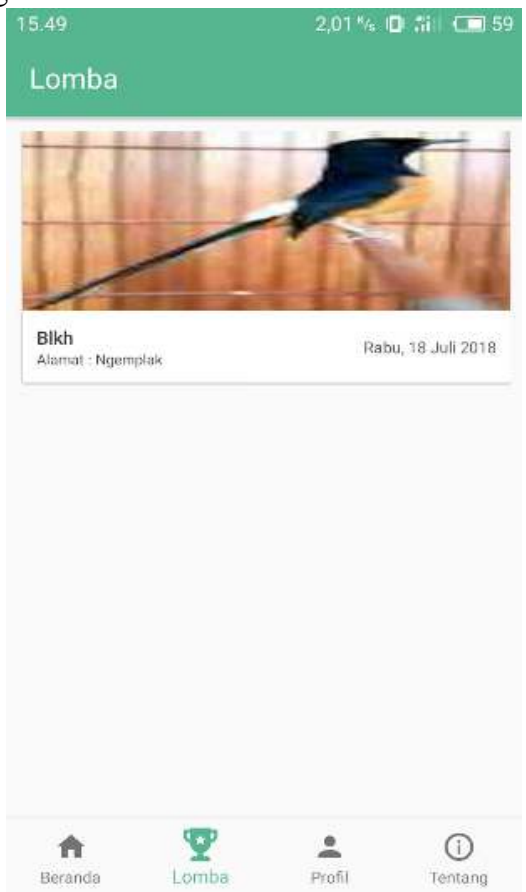

Gambar 13 halaman form lomba

Keterangan gambar 13 halaman form lomba, merupakan halaman daftar lomba burung yang berada di surakarta. Pengguna menekan gamabar akan muncul detail waktu, tanggal, dan alamat pelaksanaan.

m. Halaman form detail lomba burung

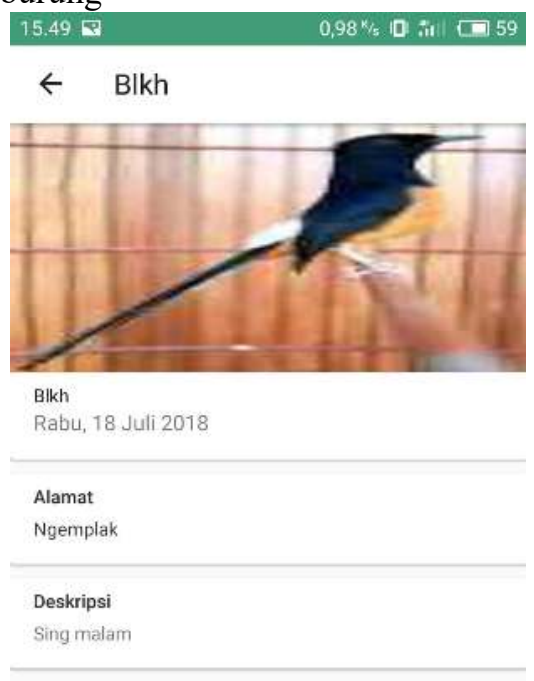

Gambar 14 halaman form detail lomba burung

Keterangan Gambar 14 halaman form detail lomba burung, merupakan halaman berisi detail dari lomba burung kapan dilaksanakan, lokasinya mana dan diskripsi perlombaan.

n. Halaman form tentang

GO INFOTECH: JURNAL ILMIAH STMIK AUB Vol. 24, No. 1, Juni 2018 : 28 - 40 


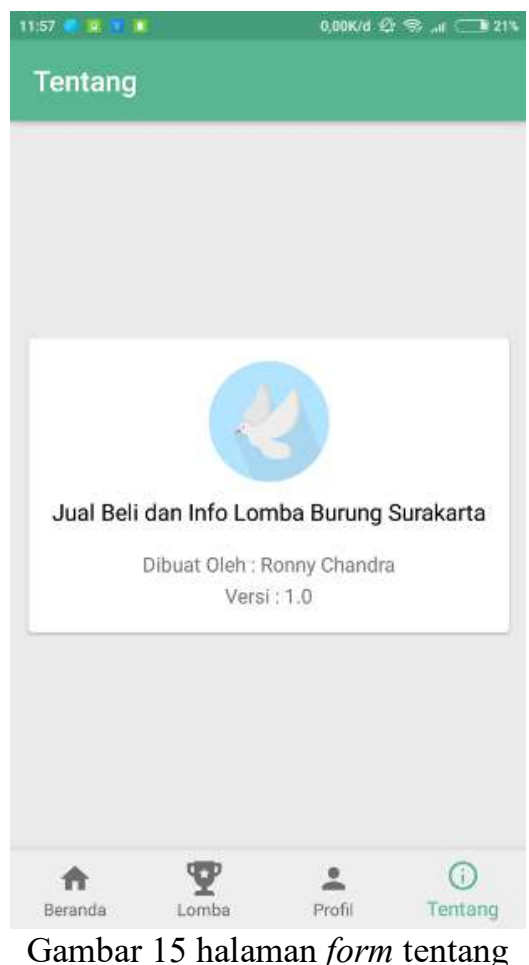
aplikasi.

Keterangan gambar 15 halaman form tentang merupakan halaman yang bersisi versi

\section{KESIMPULAN}

Hasil perancangan Aplikasi Jual Beli dan info lomba burung Surakarta terdiri dari flowchart, use case diagram dan activity diagram. Pengembangan sistem menggunakan Bahasa pemrograman Android Studio sebagai localhost XAMPP dan database MySQL. Aplikasi Jual Beli dan info lomba burung Surakarta, digunakan sebagai media untuk jual beli burung dan informasi lomba burung yang bisa langsung diproses dengan menggunakan smartphone. Adanya Aplikasi Jual Beli dan info lomba burung Surakarta ini diharapkan dapat mempermudah proses jual beli burung di wilayah Surakarta, selain itu dapat mempermudah user untuk mengetahui info lomba dengan cepat.

\section{SARAN}

Aplikasi Jual Beli dan Info Lomba Burung Surakarta dapat dikembangkan lagi sebagai berikut: halaman Jual Beli burung ditambahkan halaman form transfer bayar ke rekening penjual, halaman Lomba Burung ditambahkan halaman form detail harga tiket di lomba tersebut.

\section{DAFTAR PUSTAKA}

[1] Abdullah, Dahlan 2016. Sistem Informasi Penjualan berbasis web menggunakan metode Unified Modeling Language (UML). Jurnal:Universitas Malikussaleh Aceh

[2] Farizah, Nafhah. 2017. Makalah artikel menurut para ahli

[3] (http://burungkenari.wordpress.com)

[4] (http://adiputrasembilan.blogspot.com/p/pengertian-burung-peliharaan.html) 
[5] Jogiyanto. 2005. Analisis \& Desain Sistem Informasi : Pendekatan Terstukter, Teori dan Praktis Aplikasi Bisnis. Yogyakarta : Penerbit Andi.

[6] Krisdian, Yohanes dan Nugroho, Ernes Cahyo. 2015. Aplikasi Lomba Burung Berbasis Android. Jurnal Ilmiah Go Infotech, Vol 21 No 2 Desember 2015, hal 37-41

[7] Prasetyawan, Wahyu. 2016. Perancangan Sistem Penjulan Berbasis Web pada CV. Kicau Burung Kabupaten Kudus. Jurnal:Universitas Dian Nuswantoro Semarang.

[8] Randha. 2016. Pengertian pertandingan dan perlombaan.

[9] Safaat, Nazruddin. 2012. Android Pemrograman Aplikasi Mobile Smartphone dan Tablet PC Berbasis Android . Bandung : Informatika Bandung.

[10] Sandi. 2012. Definisi Pengertian dan Fungsi XAMPP Lengkap. https://indoskripsi.com diakses pada 22 November 2017.

GO INFOTECH: JURNAL ILMIAH STMIK AUB Vol. 24, No. 1, Juni 2018 : 28 - 40 